\title{
The Use of Language Learning Strategies in Speaking Subject
}

\author{
Santri E.P. Djahimo, Linda I. Rupidara, Josua Bire \\ \{sunthree_dj@yahoo.com,lrupidara@yahoo.com,josua.bire@yahoo.com\} \\ University of Nusa Cendana, Indonesia
}

\begin{abstract}
This study aims at answering two questions about the types of learning strategies used by the majority of the third semester students of the English Department of Nusa Cendana University Kupang and whether or not the students' backgrounds define their choice of language learning strategies. Rebecca Oxford's Strategy Inventory for Language Learning (SILL) questionnaire has been used to describe and explain phenomena related to learning strategies of the twenty-eight students involved in the research. The result reveals that $61 \%$ of all assessed students have used metacognitive strategy to other strategies. This implies that students from both groups cautiously monitored their ability and progress in learning English. In the meantime, the other result shows that positive output has been strongly seen in regards to students' major. Metacognitive strategy has been used by $81.8 \%$ students from natural science, $22.2 \%$ students from social science and $57.1 \%$ students from language department.
\end{abstract}

Keywords: language learning strategies, SILL, metacognitive strategy, speaking subject

\section{Introduction}

As mandated by Indonesian curriculum, English is compulsory for students to learn at school starting from elementary level. Even though it is considered as a foreign language, yet English proficiency is expected. As consequence to this, its mastery level will be tested as a part of the national standardized examination. Despite this fact, many students find English as a difficult subject to learn and they also find it challenging when they want to master the language. One may say that it is probably linked to the ability of individuals to cope with challenges when learning a foreign language. However, Brown (2007a:1-3) considers that learning process is affected by a combination of several internal and external factors. Internal factors include learners' characteristics, ages, aptitude, motivation, personalities, cognitive styles, hemisphere specialization and learning strategies. The external factors refer to learning and physical learning environment, in addition to elements of instructional variables, contexts and purposes.

This research was conducted in the attempt to explore one of the internal factors, in this case, the learning strategy of the third semester students of the English Department of Nusa Cendana University, Kupang. The subject of the research was selected based on the consideration that students who specialized in English study would have learnt English more comprehensively compared to those of other field of study, and therefore, it will be interesting to learn about strategies that they apply in their learning. Yet, prior to this study, the researchers had carried out a number of observations on students' performance in speaking 
classes. It appeared that there were huge gaps at the level of participation, capacity and proficiency among students. Those observations have also shown that in spite of being at their second semester of study, quite a lot of students continued to struggle with basic grammatical problems, such as poor sentence formation, incorrect use of tenses and limited word choices. Only small portion of the students excelled in most learning interactions as well as in assignments and tests.

Witnessing circumstances of learning interactions in the second semester, this study followed the track of those students in their third semester speaking subject, taking into account that starting the new semester students will need to adapt to new topics. This would be a good reason for students to find effective ways to help them make progress in the subject. Thus, this study was conducted with the following objectives: First, to find out the types of learning strategies have been used by the majority of the third semester students of the English Department of Nusa Cendana University Kupang; Second, to reveal whether or not students' former high-school majors have defined their choice of language learning strategies.

This research used descriptive analysis in finding out each and every student's learning strategy that has helped him/her in language learning, particularly, in speaking subject. The instrument used for data collection was the Strategy Inventory for Language Learning (SILL) questionnaire developed by Rebecca Oxford, which measured communicative competence of language learners. This study has been focused on twenty-eight students as primary sources of information and their inputs were treated as case studies. Hence, outputs of this study will be exclusive to its intended subjects of the research.

\section{Learning as conscious process of acquiring language}

Learning implies a conscious process of accumulating knowledge in an educational setting (Yule, 2010:187). In this perspective, learning a language requires a person to use his or her innate capacity to gain knowledge about all aspects of the language to develop skills and competence in using that language (Patel \& Jain, 2008:36). We can say that language learning is a conscious process to master a language, which requires active role of the learner. Theoretically, language learning links to psycholinguistic and cognitive processes involved in learning a language, with the ultimate goal is to be able to comprehend and produce it in unrehearsed situation (Brown, 2007a:119).

Learning refers to the process of developing a complex set of skills, both receptive and productive skills. Thus, mastering a language represents an individual's continuous investment in time and efforts to be capable in the language through combination of observation, focus, practice, monitoring, correction and direction (Brown, 2007b:258). Language learning means studying about grammar, vocabulary and pronunciation of the language in order to help someone know when to use certain words or phrases of the language accordingly. It is also correct when one points out language learning as checking on dictionary to learn vocabularies, listening to a program, movie or song (using the target language) to learn about how words are pronounced, then imitating them. 


\section{Does language learning need strategies?}

The term "strategies" has been applied in explaining general approaches and to specific actions or techniques to learn a second or foreign language. There are various terms used by experts that refer to strategy and those terms are: technique, tactic, and move (Cohen, 1991:5). Strategies can also be explained as "specific methods of approaching a problem or task, modes of operation for achieving a particular end, planned designs for controlling and manipulating certain information" (Brown, 2007a:119). In practical terms, strategy is about drawing plans to achieve our goal. It is also about manipulating positive and negative aspects to allow us getting what we want or expect. If we want to get high score in Speaking, the strategy is what we need do to make it happen. A strategy requires a person to realize what she or he has and likewise what she or he does not have, in order to use the knowledge to solve issues that she or he faces. In other words, strategies are beneficial if they meet the conditions to "make learning easier, faster, more enjoyable, more self-directed, more effective and more transferable to new situations (Oxford, 2003:8).

Language learning strategies (LLSs) are defined by Oxford and Cohen (1992:1) as steps and actions taken by learners to improve the development of their language skills. In the perspective of Brown (2007b:258), language learning is associated with "strategic investment" in language learning, which without it one cannot optimize his or her potentials to be successful in acquiring the competence, specifically in language, as advance as expected. This statement is coherence with the argument presented by Rubin, as quoted by Hardan (2013:1715), defines language-learning strategies as presentation of behaviors, steps or techniques that language learners adopt to facilitate their learning that aims at successful learning achievement.

LLSs is drawing plans to master the language. It is also about how to become competent and fluent in language. Language learning strategies can be: imitating the native speakers, using flashcards to memorize new vocabularies, listening to songs and watching movies to be familiar with pronunciation of words, etc. LLSs should enable learners to organize their learning problem, goal orientated, autonomously and self directive, which involve considerable degree of consciousness, advance planning as well as progress evaluation (Jakel, 2015:32).

\section{$4 \quad$ Rebecca oxford's terminologies on language learning strategies}

There are numerous studies on language learning strategies (LLSs). Each of those studies has developed taxonomies according to the conceptual framework constructed by different experts (Zare, 2012; Hardan, 2013; El Aouri, 2013; Oxford, 2003; Razmjoo \& Ardekani, 2011). However, this study chooses to use Oxford's Strategy Inventory of Language Learning (SILL), which has been acknowledged as the most influential instrument in LLSs research in measuring overall language proficiency, language learners, beliefs and cognitive style (Yesilbursa \& Ipek, 2013).

The LLSs taxonomy developed by Oxford consists of 2 (two) main categories, namely the Direct Strategies and Indirect Strategies. The direct strategies are comprised of memory, cognitive, and compensation strategies. The second sub category is labelled as Indirect Strategies, which include metacognitive, affective and social strategies.

Functions of each sub category under the Direct Strategies can be explained as 
follows:

- The memory strategy is useful to help learners to link one L2 item or concept with another in the attempt to retrieve information in orderly manner. This strategy includes techniques to remember effectively, recall and transfer information needed in language use. It helps students to keep important information in their memory (Hardan, 2013:1721). Memory strategy adopts simple principles such as association making and reviewing. For example, new words and phrases can be associated with visual images, sound or motion to help learners in the memory storage for future use in communication (UGC ICOSA, 2013).

- Cognitive strategy helps to manipulate the language material in direct ways. The use of drills in practicing the language and the use of dictionary to find difficult words are actions reflected the use cognitive strategy (Hardan, 2013:1722). It helps students in selecting relevant information and eliminating those that are irrelevant (Kalati, 2016:5). Note taking, reasoning, analyzing, summarizing, synthesizing and outlining are practices connected to the use of cognitive strategy (El Aouri, 2013:52).

- Compensation strategy is action that enables learners to use the target language to compensate for the inadequate repertoire of the language skills particularly on grammar and vocabulary to produce spoken or written to aid in speaking and/or writing. It allows students to adjust the message, combine words or switch to L1 use (Kalati, 2016:5). Compensation strategy is employed when learners face a breakdown in speaking or writing (Zare, 2012:165). Using mime or gesture, adjusting or approximating the message and using a circumlocution or synonym are among other practical examples of the compensation strategy (Valdes, 2012). A study done among the third millennium EFL learners suggests that guessing strategy is used more in online interactions and networking due to the abundance of materials, as well as blended and compound words emerging from the new technology (Shakarami, Hajhashemi \& Caltabiano, 2017:246).

The Indirect Strategies provide indirect support for language learning through focusing, planning, evaluating, seeking opportunities, controlling anxiety, increasing cooperation, empathy and learning through social interactions. It is not directly related to the interaction of the language itself (Fewell, 2010: 161). These strategies consist of metacognitive, affective and social strategies. How these strategies work is elaborated below:

- Metacognitive is a strategy considered as "thinking about thinking" (Yunus, Kaur \& Singh, 2014). The concept of metacognitive strategy or metacognitive process is also referred as meta-reasoning because it involves goal-setting, updating, monitoring, selfregulation and controlling reasoning, problem-solving and decision making (Salazar, 2017). There are two important dimensions, which are: metacognitive knowledge or reflection, and metacognitive regulation. Metacognitive knowledge or reflection refers to the capacity of recognizing one's own cognitive skills, knowledge of specific tasks and use of strategies. Meanwhile metacognitive regulation involves monitoring and controlling one's cognitive processes (Ibid.).

- Affective strategy relates to students' feeling. It allows learners to control their mood and anxiety level, talk about their feelings, use positive self-talk and self-rewarding (El Aouri, 2013:52). Affective strategy deals with managing emotions, both positive and negative. As such, it assists students to manage their emotions, motivation and attitudes for conducive learning (Zare, 2012:165). The relationship between affective strategies and learning and acquisition of L2 is contextually dependent (Oxford, 2003:14), but a positive affective environment helps learning conditions in general (British Council, $\mathrm{n} / \mathrm{d}$ ).

- Social strategy involves learning by interaction with others (Abdul Rahman \& Maarof, 
2015). Social learning strategy has three basic techniques, namely: cooperating with others, asking questions and empathizing with others (Bright Hub, n/d). Lan and Oxford argue that social strategies have several functions include: asking questions in L2, receiving answers, correcting mistakes, establishing cooperation, trying to study feelings and thoughts of people of the targeted culture (Varisoglu, 2016:982). This strategy has two principal characteristics, as follow: to encourage feedback and interaction, but it involves actions that are carried out with the help of others to accomplish understanding, learning and keeping information (Etxebarria, Garay \& Romero, 2012:275).

\section{$5 \quad$ Students' preferential types of language learning strategies in speaking subject}

Speaking is one of the productive components in language learning aside of writing. It is the form of oral communication (Brown, 2007b:322) and is a prominent goal of L2 learning due to increasing intention to communicate and interact with native speakers of various languages. In language learning, a learner is expected to develop his or her speaking ability in producing verbal communicative utterances beyond his or her linguistics skills.

Speaking refers to oral communication skill, which is important to achieve larger goals in language learning namely to build communicative competence (Hymes in Bire, 2017:79), pragmatics competence (Wyner, 2014; Kasper, 1997), or expressive communication (Sheth, 2016). Proficiency in speaking is inseparable from mastering the receptive skills, particularly listening (Brown, 2007b:323). The Input Hypothesis proposed listening comprehension and reading as primarily importance in language program and speaking ability, as well as writing ability, will develop at a later acquisition stage (Bire, 2017:52). Speaking skill is closely linked to listening skill because it involves the communicator and the communicant in the process of encoding and decoding information, messages or dialogues. However, in this study, speaking refers to English Speaking subject and classes where productive component of English is being studied.

As it has been previously, this research aims to examine which strategies in Speaking subject that are highly used by third semester students of English Study Program and trends on the use of Language Learning Strategies (LLS) defined by students' former high-school majors. For effective management of the data collection and later its analysis, this study classified the students into two groups, namely the upper level and lower level group. The research used Speaking 2 scores to select the research subject. The focus of the study was students who had higher score, which is between 3.00 and above and those of lower scores, i.e. between 2.00 and 2.25 . Overall this study has involved 28 students from those groups, whose inputs were treated as case studies. Both upper level and lower level groups were equally represented by 14 students each, randomly chosen.

The following table presents the result of summative calculation of SILL questionnaire. It shows that the highly used strategy has been concentrated in part $\mathrm{D}$, or the metacognitive strategy. It can be seen from the students' answers that 11 out of 14 students (78.57\%) chose part D. Other parts, in this case part A (memory strategy), part C (compensation strategy) and part F (social strategy) has been chosen by 3 different students, i.e. by Student X1, Student X7 and Student X13. No highest score has been found in part B. 
Table 1. Language Learning Strategy (LLS) used by Upper Level Students

\begin{tabular}{|l|l|l|l|l|l|l|l|}
\hline No & $\begin{array}{c}\text { Student } \\
\text { ID }\end{array}$ & Part A & Part B & Part C & Part D & Part E & Part F \\
\hline 1 & $\mathrm{X} 1$ & 3.22 & 4.00 & 3.67 & 4.00 & 3.17 & 4.33 \\
\hline 2 & $\mathrm{X} 2$ & 3.00 & 3.64 & 3.67 & 4.56 & 2.83 & 3.33 \\
\hline 3 & $\mathrm{X} 3$ & 3.67 & 3.79 & 4.00 & 4.78 & 3.83 & 4.67 \\
\hline 4 & $\mathrm{X} 4$ & 2.89 & 3.57 & 3.83 & 4.11 & 3.83 & 3.00 \\
\hline 5 & $\mathrm{X} 5$ & 2.78 & 3.86 & 2.83 & 4.22 & 3.67 & 3.50 \\
\hline 6 & $\mathrm{X} 6$ & 3.67 & 4.57 & 4.17 & 4.78 & 3.83 & 4.17 \\
\hline 7 & $\mathrm{X} 7$ & 4.11 & 3.14 & 3.67 & 3.78 & 3.17 & 3.33 \\
\hline 8 & $\mathrm{X} 8$ & 3.78 & 4.00 & 4.17 & 4.78 & 4.67 & 3.17 \\
\hline 9 & $\mathrm{X} 9$ & 4.22 & 4.43 & 3.67 & 5.00 & 3.00 & 4.33 \\
\hline 10 & $\mathrm{X} 10$ & 3.33 & 3.43 & 3.00 & 4.22 & 3.33 & 2.83 \\
\hline 11 & $\mathrm{X} 11$ & 3.00 & 4.07 & 4.50 & 4.78 & 4.50 & 4.00 \\
\hline 12 & $\mathrm{X} 12$ & 2.89 & 3.50 & 3.83 & 4.33 & 3.33 & 3.50 \\
\hline 13 & $\mathrm{X} 13$ & 3.00 & 3.29 & 4.33 & 4.00 & 4.00 & 2.50 \\
\hline 14 & $\mathrm{X} 14$ & 4.00 & 4.43 & 3.83 & 4.89 & 4.50 & 4.17 \\
\hline
\end{tabular}

As shown in Table 1, this study found that metacognitive strategy is the most identified strategy among Students on the upper level group in Speaking 3. This implies that many students were adopting strategies to pay attention, consciously searching for practice opportunities, planning for language tasks, self-evaluating progress and monitoring error.

In the meantime, this study also recorded other strategies adopted by students, that is memory strategy (part A), compensation strategy (part C), and social strategy (part F). High use of memory strategy shows that students remember language through the use of various means, such as rhymes, flashcards or acting out to learn English. It is also about connecting English learning to something that makes it easier for the learners to remember its means or its usages. Then high use of compensation strategy implies that students use clues to guess intelligently about what they learn and make up their limited knowledge, by gestures, making guesses, and exploring synonyms are among other compensational approaches that can be used.

With respect to the lower level students, it was observed that part D was also the highly used strategy by lower level students as shown in Table 2 below. The difference is in lower level group only 6 students scored part D the highest, which represents $42.85 \%$ of total students. Three students choose part E the highest, but one of them has scored the same on part $\mathrm{E}$ and $\mathrm{F}$. We can also see that part $\mathrm{C}$ has been chosen by 3 students, while part $\mathrm{A}$ and $\mathrm{F}$ have been chosen by one student each. Similar to the result of upper level group students, no highest score has been found in part B, which conceptually deals with how they acquire knowledge about language and shows more direct link to individual learning tasks and drilling practices in learning English.

Corresponds to the second question: do students' backgrounds define their choice of language learning strategies? The study found out that students who previously have majored in natural science and language choose part D as the most frequently used strategy. Nine out of eleven students from natural science department use metacognitive strategy, which represents $81.8 \%$ of students from this department. Four out of seven students $(57.14 \%)$ who previously studied in language department also choose part D. But, only 2 out of $9(22.22 \%)$ students from social sciences choose part D. There is one student who does not answer the question. 
Table 2. LLS used by Lower Level Students

\begin{tabular}{|c|c|c|c|c|c|c|c|}
\hline No & $\begin{array}{l}\text { Student } \\
\text { ID }\end{array}$ & Part A & Part B & Part C & Part D & Part E & Part F \\
\hline 1 & Y1 & 3.44 & 3.50 & 3.83 & 3.44 & 3.33 & 3.17 \\
\hline 2 & $\mathrm{Y} 2$ & 3.00 & 3.14 & 3.17 & 4.33 & 2.83 & 2.67 \\
\hline 3 & Y3 & 3.44 & 3.57 & 4.17 & 3.78 & 3.50 & 4.00 \\
\hline 4 & Y4 & 3.00 & 2.43 & 2.50 & 3.11 & 2.83 & 2.83 \\
\hline 5 & Y5 & 3.33 & 3.64 & 3.33 & 3.89 & 2.67 & 4.00 \\
\hline 6 & Y6 & 3.44 & 3.36 & 3.50 & 3.67 & 3.17 & 3.00 \\
\hline 7 & Y7 & 3.11 & 4.00 & 4.33 & 4.33 & 4.50 & 4.50 \\
\hline 8 & Y8 & 2.89 & 3.21 & 2.83 & 4.11 & 2.67 & 3.33 \\
\hline 9 & Y9 & 2.56 & 3.07 & 3.17 & 3.78 & 3.67 & 2.50 \\
\hline 10 & Y10 & 3.89 & 3.86 & 3.67 & 3.78 & 3.33 & 3.33 \\
\hline 11 & Y11 & 3.78 & 3.21 & 4.33 & 3.89 & 3.83 & 4.00 \\
\hline 12 & Y12 & 3.00 & 3.50 & 2.83 & 4.00 & 4.67 & 3.83 \\
\hline 13 & Y13 & 3.56 & 3.93 & 3.50 & 3.78 & 4.00 & 3.00 \\
\hline 14 & Y14 & 2.56 & 3.36 & 2.67 & 4.67 & 3.67 & 4.50 \\
\hline \multicolumn{2}{|c|}{ AVERAGE } & 3.21 & 3.41 & 3.42 & 3.90 & 3.48 & 3.48 \\
\hline
\end{tabular}

\section{Conclusion}

As previously have been mentioned, this study aims to find answers to two questions. First question is: "What learning strategies are highly used by the third semester students in Speaking subject?" and the second is: "Do students with different majors in high school adopt different language learning strategy?" On the first research question, findings from Strategy Inventory of Language Learning (SILL) questionnaire show that most students choose part D as the highly used strategy. This shows highly use of metacognitive strategy among students, compared to other strategies. This fact tells that students from the upper level and lower level groups monitored their graphs of progress and their ability to learn English. And, in regards to the second question, the relation between majors in high school and the choice of learning strategies seemed stronger as $81.8 \%$ of those of natural science chose metacognitive strategy, while only $22.2 \%$ from social science and $57.1 \%$ from language department. As such, students from natural science department had the tendency to choose metacognitive strategy, which was contrast to students from social science and language department.

\section{References}

[1] Bire, Jos. 2017. Second Language Acquisition. Kupang: Undana Press.

[2] Brown, H.D. 2007a. Principles of Language Learning and Teaching. Fifth Edition. New York: Pearson Longman.

[3] 2007b. Teaching by Principles: An Interactive Approach to language Pedagogy. $3^{\text {rd }}$ Edition. New York: Pearson Longman.

[4] Cohen, A. 1991. Strategies in Target-Language Learning: Insights from Research. ERIC.

[5] El Aouri, Zahra. 2013. Defining Language Learning Strategies: Implication for Research. IOSR Journal of Humanities and Social Science (IOSR-JHSS) Vol. 13 Issue 4, pp. 50-54.

[6] Etxebarria, A., Garay, U. \& Romero, A. 2012. Implementation of Social Strategies in 
Language Learning by Means of Moodle. Journal of Language Teaching and Research Vol. 3 No.2, pp. 273-282.

[7] Fewell, Norman. 2010. Language Learning Strategies and English Language Proficiency: An Investigation of Japanese EFL University Students. TESOL Journal Vol 2. Pp. 159-174.

[8] Hardan, A.A. 2013. Language Learning Strategies: A General Overview. Procedia Social and Behavioral Sciences 106 pp 1712-1726.

[9] Jakel, Nils. 2015. Use and Impact of Language Learning Strategies on Language Proficiency: Investigating the Impact of Individual Difference Variables and Participation in CLIL Streams. Dissertation. Bochum University.

[10] Kalati, Ezat A. 2016. Learning Strategies in Second Language Acquisition. Research and Reviews.Journal of Educational Studies Vol.2 Issue 4 pp 4-8.

[11] Marefat, H. and Shirazi, M.A. 2003. The Impact of Teaching Direct Learning Strategies on the Retention of Vocabulary by EFL Learners. The Reading Matrix Vol. 3 No.2. pp. 47-62.

[12] Oxford, R.L. 2003. Language Learning Styles and Strategies: An Overview. Learning Styles and Strategies. GALA.

[13] Patel, M.F. \& Jain, P.M. 2008. English Language Teaching (Methods, Tools \& Techniques). Jaipur: Sunrise Publisher \& Distributors.

[14] Razmjoo, S.A. \& Ardekani, S.G. 2011. A Model of Speaking Strategies for EFL Learners. The Journal of Teaching Language Skills (JTLS) 3(3), pp. 115-142.

[15] Shakarami, A., Hajhashemi, K. \& Caltabiano, N.J. 2017. Compensation still Matters: Language Learning Strategies in Third Millennium ESL Learners. Online Learning, 21(3), pp. 235-250.

[16] Varisoglu, Mehmet C. 2016. The Importance of Strategies of Social Language Learning and Cooperative Learning in the Process of Teaching Turkish as Foreign Language. Educational Research and Reviews Vol. 11 (10), pp. 981-986.

[17] Yesilbursa, A. and Ipek, O.F.2013. Why Is It Necessary to Validate SILL? ProcediaSocial and Behavioral Sciences 70. pp 887-893.

[18] Yule, G. 2010. The Study of Language. $4^{\text {th }}$ Edition. New York: Cambridge University Press.

[19] Yunus, N.M., Kaur, K. \& Singh, M. 2014. The use of indirect strategies in speaking: Scanning the MDAB students. Procedia 123, pp. 204-214.

[20] Zare, P. 2012. Language Learning Strategies Among EFL/ESL Learners: A Review of Literature. International Journal of Humanities and Social Science Vol. 2 No.5 pp. 162-169.

[21] Abdul Rahman, N.A. \& Maaafor, N. 2015. The Relationship between Language Learning Strategies and Students' Motivation in Learning English as a Second Language. ResearchGate. Retrieved February 2, 2019 from https://www.researchgate.net/publication/318489292_The_Relationship between_Lan guage_Learning_Strategies_and_Students'_Motivation_in_Learning_English_as_A_Se cond Language

[22] Bright Hub. n/d. Social Strategies for Second Language Learning: Tips for Getting Other People to Help You! Retrieved February 4, 2019 from https://www.brighthubeducation.com/language-learning-tips/16477-social-strategiesin-learning-a-second-language/.

[23] British Council. n/d. Affective Strategies. Retrieved February 4, 2019 from https://www.teachingenglish.org.uk/article/affective-strategies. 
[24] Kasper, G. 1997. Can Pragmatic Competence be Taught? National Foreign Language Resource Center University of Hawai'i. Retrieved October 23, 2018 http://www.nflrc.hawaii.edu/NetWorks/NW06/

[25] Oxford, R. \& Cohen, A.D. 1992. Language Learning Strategies: Crucial Issues of Concept and Classification. Retrieved September 7, 2018, from ResearchGate: https://www.researchgate.net/profile/Andrew_Cohen12/publication/234741576_Langu age_Learning_Strategies_Crucial_Issues_of_Concept_and_Classification/links $/ 55$ a 525 b608ae5e82ab1 f86bd/Language-Learning-Strategies-Crucial-Issues-of-Concept-andClassification.pdf?origin=publication_detail, https://.

[26] Salazar, Marcela. 2017. Metacognition: Thinking about Thinking Improves Learning. Retrieved February 2, 2019 from Cognifit - Health, Brain \& Neuroscience https://blog.cognifit.com/metacognition-improves-learning/

[27] Sheth, T.D. 2016. Expressive Communication Skills in English: A Criterion for NonNative L2 Students. International Journal of Humanities Social Sciences and Education (IJHSSE)Vol. 3 Issue 12, pp 43-47. Retrieved October, 18, 2018 from ResearchGate:

https://www.researchgate.net/publication/311933083_Expressive_Communication_Ski lls in_English_A_Criterion_for_Non-Native_L2_Students.

[28] UGC ICOSA. 2013. Learner Training $4-$ Social and Affective Strategies. $\begin{array}{lllll}\text { Retrieved } & \text { February } & 4, & 2019 & \text { from }\end{array}$ http://elss.elc.cityu.edu.hk/elss/Resource/Social\%20and\%20Affective\%20Strategies/

[29] Valdes, Krliux. 2016. Indirect and Direct Learning Strategies. Prezi.com. Retrieved February 4, 2019 from https://prezi.com/qi4qnrlu3gyl/indirect-and-direct-learningstrategies/

[30] Wyner, L. 2014. Second Language Pragmatic Competence: Individual Differences in ESL and EFL Environments. Retrieved October 23, 2018 from www.tc.columbia.edu/tesolalwebjournal. 